\title{
Comparison of the effects of triamcinolone acetonide or platelet-rich plasma on expression of extracellular matrix-related genes in equine healthy chondrocytes in vitro
}

\author{
Heloisa Einloft Palma ${ }^{*}$ Miguel Gallio ${ }^{2}$ iD Gabriele Biavaschi da Silva ${ }^{3}$ Camila Cantarelli $^{3}$ \\ Kalyne Bertolin ${ }^{3}$ Patrícia Wolkmer $^{1}$ Julien Wergutz ${ }^{4}$ Luciana Maria Fontanari Krause ${ }^{4}$ \\ Alexandre Krause ${ }^{5}$ Alfredo Quites Antoniazzi ${ }^{3}$ Karin Erica Brass $^{3}$ Flavio Desessards De La Corte $^{3}$
}

${ }^{1}$ Centro de Ciências da Saúde e Agrárias, Universidade de Cruz Alta (UNICRUZ), 98020-290, Cruz Alta, RS, Brasil. E-mail: heinloft@hotmail.com. ${ }^{*}$ Corresponding author.

${ }^{2}$ Curso de Medicina Veterinária, Instituto de Desenvolvimento Educacional do Alto Uruguai (IDEAU), Getúlio Vargas, RS, Brasil.

${ }^{3}$ Departamento de Clínica de Grandes Animais, Universidade Federal de Santa Maria (UFSM), Santa Maria, RS, Brasil.

${ }^{4}$ Departamento de Saúde, Universidade Franciscana (UFN), Santa Maria, RS, Brasil.

${ }_{5}^{5}$ Departamento de Clínica de Pequenos Animais, Universidade Federal de Santa Maria (UFSM), Santa Maria, RS, Brasil.

ABSTRACT: In healthy cartilage, chondrocytes maintain an expression of collagens and proteoglycans and are sensitive to growth factors and cytokines that either enhance or reduce type II collagen synthesis. In osteoarthritis, pro-inflammatory cytokines, such as IL-6, induce overexpression of metalloproteinases (MMP) and decreasing synthesis of aggrecan. Use of chondroprotectors agents, such as Platelet-Rich Plasma (PRP) and triamcinolone (TA) are alternatives to reduce the progression of joint damage. In this study, we used chondrocytes extracted from metacarpophalangeal joints of healthy horses as the experimental model. Cells were treated in vitro with PRP or TA. No differences were observed between these treatments in comparison to the control group when the expressions of MMP9, MMP13, IL-6 and ACAN genes were evaluated $(P<0.05)$. With these results, we can suggest that the treatments were not deleterious to equine cultured chondrocyte, once they did not stimulate MMPs and IL-6 synthesis or caused changes in ACAN.

Key words: $M M P s, I L-6$, aggrecan, cartilage, osteoarthritis.

Comparação dos efeitos do acetonido de triancinolona ou plasma rico em plaquetas na expressão de genes relacionados à matriz extracelular de condrócitos in vitro de equinos adultos

RESUMO: Na cartilagem saudável, os condrócitos mantêm a expressão de colágenos e proteoglicanos, sendo sensíveis a fatores de crescimento e citocinas que aumentam ou reduzem a síntese de colágeno tipo II. Na osteoartrite, citocinas pró-inflamatórias, como a IL-6, estimulam a expressão de metaloproteinases (MMP) e reduzem a síntese de agrecano. O uso de condroprotetores, como o Plasma Rico em Plaquetas (PRP) e triancinolona (TA) é uma alternativa para se reduzir a progressão do dano articular. Neste estudo foram usados condrócitos extraídos das articulações metacarpofalangeanas de equinos saudáveis. As células foram tratadas in vitro com TA ou PRP. Não foram observadas diferenças entre os tratamentos comparando-se com o grupo controle quanto à expressão genética de MMP-9, MMP-13, IL-6 e ACAN ( $p<0,05)$. Assim, pode-se sugerir que os tratamentos não foram deletérios ao cultivo de condrócitos, uma vez que não estimularam a síntese de MMP e IL-6 e nem causaram alterações no ACAN.

Palavras-chave: $M M P S, I L-6$, agrecano, cartilagem, osteoartrite.

\section{INTRODUCTION}

Articular cartilage is composed of chondrocytes embedded in an extracellular matrix (ECM) formed mainly by type II collagen and proteoglycan aggrecan molecules, which they synthesize and degrade. In cases of osteoarthritis (OA) there is a disturbance in synthetic and resorptive activities of the chondrocytes that results in loss of cartilage matrix components and deterioration. The clinical consequences of OA are local inflammation, joint effusion, pain and progressive lameness. These clinical signs occur mainly because OA involves cartilage degradation leading finally to bone-onbone contact with loss of articular strength and inflammation (GOLDRING \& GOLDRING, 2004; TORRERO \& MARTÍNEZ, 2015).

Pro-inflammatory cytokines are critical mediators of the enhanced catabolism of joint tissue involved in OA. Interleukin-1 $\beta$ (IL1 $\beta$ ), Tumor 
Necrosis Factor alpha (TNF- $\alpha$ ) and Interleukin-6 (IL6) are pro-inflammatory cytokines involved in the pathophysiology of OA, inducing overexpression of metalloproteinases (MMPs) and decrease synthesis of macromolecules, including aggrecan (PORÉE et al., 2008; KAPOOR et al., 2011).

Usual treatment for osteoarthritis includes the use of corticosteroids, such as triamcinolone acetonide (TA), which have been associated with beneficial effects on articular cartilage. For instance, SANDLER et al. (2004) reported that TA when combined with growth factors enhanced anabolic metabolism within the articular cartilage. However, many reports have described this class of drugs as damaging the joints. DECHANT et al. (2003) observed that the treatment with TA in cartilage explants in vitro was detrimental to cartilage metabolism.

Developing strategies for intra-articular therapies in horses that promote tissue regeneration is very important, and, for this, platelet-rich plasma (PRP) has been a potentially regenerative therapy (TEXTOR \& TABLIN, 2013). It is considered a good therapeutic alternative because it is a cheap technique and with a low possibility of reactions by the recipient, since its own biological material is used (HUR et al., 2014). However, these current therapeutic options should not cause damage to chondrocytes, since this could aggravate the conditions of joint disease.

The IL-6 is one of the major cytokines presents in damaged articular cartilage. One of the principal functions of this cytokine is stimulate the expression of MMPs and decrease the expression of type II collagen (KAPOOR et al., 2011; ORTOLANO \& WENZ, 2014). In relation to MMPs, many of them are synthesized by chondrocytes. MMP-9 and MMP-13 can cleavage the type II collagen, disrupting collagen network. The measurement of the ACAN expression is due to the fact that aggrecan is the predominant proteoglycan in articular cartilage, and its lost can also cause destruction of collagen network (ISHIGURO et al., 2002). Based on this, our study aimed to analyze the potential interference of administration of TA and PRP in culture of healthy chondrocytes, extracted from healthy metacarpophalangeal joints of horses, in relation to the gene expression of MMP13 and MMP9, IL-6 and ACAN.

\section{MATERIALS AND METHODS}

\section{Isolation of articular chondrocytes of horses}

For the accomplishment of this study, metacarpophalangeal joints of five adult horses were collected from an abattoir in Brazil. Animals were considered healthy through clinical and radiographic evaluation. Limbs were sectioned at the carpometacarpal joint and cleaned and the hair removed.

Under aseptic conditions in a laminar flow chamber, the selected joints were surgically exposed and the cartilage was removed in small fragments using a chizel. Chondrocytes were isolated from articular cartilage as described by CRUZ et al. (1990) with some modifications. Briefly, fragments were immediately placed in a Petri dish containing culture medium DMEM (Dulbecco Modified Eagle's Medium), supplemented with $10 \%$ fetal bovine serum (FBS), $60 \mathrm{U} / \mathrm{mL}$ penicillin, $60 \mu \mathrm{g} /$ $\mathrm{mL}$ streptomycin and $2 \mathrm{mmol} / \mathrm{L}$ glutamine. Then the cartilage fragments were washed three times and underwent enzymatic digestion in $50 \mathrm{~mL}$ conical centrifuge tube in order to isolate the chondrocytes. For this, chondrocytes were initially incubated in Pronase medium for $1 \mathrm{~h} 30 \mathrm{~min}$ and, after washing three times, were incubated in $50 \mathrm{~mL}$ conical centrifuge tubes for approximately 18 hours in collagenase medium. The two incubations that composed the digestion process were carried out at $37{ }^{\circ} \mathrm{C}$ in a humidified atmosphere with $95 \%$ air and $5 \% \mathrm{CO}_{2}$.

After digestion with collagenase, the cells were washed three times in culture medium to eliminate the enzyme and, therefore, halting digestion. Cell suspension was collected into $50 \mathrm{~mL}$ conical centrifuge tubes and the volume supplemented by addition of culture medium DMEM. Afterwards, it was allowed five minutes rest so that small fragments of cartilage eventually could be isolated from the cells. Cell suspension was then aspirated and transferred to a new $50 \mathrm{~mL}$ conical centrifuge tube, which was then centrifuged at $1200 \mathrm{rpm}(200 \mathrm{~g})$ for five minutes. After the third wash, cells were suspended in culture medium supplemented with 5\% (v/v) FBS.

The cell density of the suspension obtained was determined by manual counting in a Neubauer's hemocytometer. Cell viability was evaluated simultaneously using the Trypan Blue exclusion test. As a rule, more than $98 \%$ of viable cells were obtained in each isolation. The experiment was repeated with five different joint culture cells.

\section{Chondrocyte culture and treatments}

Chondrocytes were cultured in $60 \mathrm{~mm}$ in diameter Petri dishes or in six-well culture plates under confluence conditions at a density of $0.5 \times 10^{6} \mathrm{cells} / \mathrm{cm}^{2}$. Chondrocytes were cultured for a mean period of 21 days in DMEM culture medium 
supplemented with $10 \%$ FBS, $60 \mathrm{U} / \mathrm{mL}$ penicillin, $60 \mu \mathrm{g} / \mathrm{mL}$ streptomycin and $2 \mathrm{mmol} / \mathrm{L}$ glutamine in humidified atmosphere, at $37{ }^{\circ} \mathrm{C}$ and $5 \% \mathrm{CO}_{2}$. After an average period of 21 days, when the cells had reached a confluence of approximately $90 \%$, they were transferred to the cell culture dishes.

After reaching confluence around $90 \%$ in the culture dishes, after a period of three days average, the treatment of the cells started. For this purpose, the cell cultures were distributed in three groups $(\mathrm{G})$ : $\mathrm{G1}$ : control chondrocytes without any treatment, only medium; G2: chondrocytes + PRP (500.000 platelets/ well); G3: chondrocytes + triamcinolone $(0,06 \mathrm{mg} /$ $\mathrm{mL}$ ). The volume and doses used in each treatment were adjusted according to what is recommended for the treatment of animals presenting joint lesions in routine clinical cases. Each treatment was repeated five times. Cell viability was accessed by flow cytometry (FACSVerse cytometer, BD Biosciences), with propidium iodide staining (BD Biosciences).

\section{Preparation of PRP}

Heterologous Platelet Rich Plasma (PRP) was produced from blood collected from the jugular vein of one healthy horse, with a collection bag containing CPDA-1 as anticoagulant. After centrifugation protocol, which consisted of two steps, the first centrifugation was done with a force of $400 \mathrm{~g}$ for ten minutes, for separation of the plasma, which was immediately transferred to two new $50 \mathrm{~mL}$ conical centrifuge tubes and centrifuged again with $800 \mathrm{~g}$ strength for 10 minutes to form the platelet pellet. The supernatant was discarded, leaving $10 \mathrm{~mL}$ of PRP. PEREIRA et al. (2013) previously established this protocol in our laboratory. In order to remove the white blood cells, between the two centrifugation steps a leukocyte removal filter was used. Pellet was suspended and homogenized with a fraction of the supernatant plasma. A PRP sample and a whole blood sample were sent to the laboratory for platelet count in Neubauer's hemocytometer and confirmation of PRP concentration (three to five times higher than in whole blood) prior to use of the product inactivated in the cell culture.

\section{RNA isolation, Reverse Transcription and} Quantitative Polymerase Chain Reaction ( $q P C R$ )

Total RNA from the chondrocytes was extracted using TRIzol $^{\circledR}$ as per manufacturer's instructions. Quantification of RNA was performed using a Nano-Drop spectrophotometer, and the RNA purity was assessed by the $260 / 280 \mathrm{~nm}$ absorbance ratio (Thermo Scientific). RNA was treated with 0.1
U DNase Amplification Grade (Invitrogen) for $15 \mathrm{~min}$ at $27^{\circ} \mathrm{C}$, followed by DNase inactivation with $1 \mu 1$ of EDTA $(25 \mathrm{mM})$ at $65^{\circ} \mathrm{C}$ for $10 \mathrm{~min}$. Double-stranded complementary DNA (cDNA) was synthetized from $300 \mathrm{ng}$ of total RNA with random hexamer primers using iScript cDNA Synthesis Kit (BioRad) according to the manufacturer's instructions. Quantitative polymerase chain reactions (qPCR) were conducted in a CFX384 thermocycler (BioRad) using BRYT Green ${ }^{\circledR}$ dye and Taq DNA polymerase from GoTaq ${ }^{\circledR}$ qPCR Master Mix (Promega Corporation), with 12.5 ng of cDNA in $2 \mu 1$. A common thermal cycling program (initial denaturation at $95{ }^{\circ} \mathrm{C}$ for $5 \mathrm{~min}$ followed by 40 cycles of denaturation at $95{ }^{\circ} \mathrm{C}$ for $15 \mathrm{sec}$ and annealing/extension at $60^{\circ} \mathrm{C}$ for $30 \mathrm{sec}$ ) was used to amplify each transcript. Melting curve analyses were performed to verify product identity. Primers were validated by standard curves and the sequences are listed in table 1 . Reactions with a coefficient of determination (R2) higher than 0.98 and efficiency between 85 to $110 \%$ were considered optimized. Samples were run in duplicate and results are expressed relative to GAPDH and RPL4 levels. Data were then normalized to a calibrator sample using $\Delta \Delta \mathrm{Cq}$ method as described by PFAFFL (2001). The individual efficiencies of each primer, obtained by standard pooled sample curve from the experiment itself, were taken into account in the normalization formula. The relative abundance of each gene was analysed by ANOVA.

\section{Statistical analysis}

Two-way ANOVA was used for the statistical analysis, followed by Tukey Test. The results were considered significant when $\mathrm{p}<0.05$ and expressed as mean \pm standard deviation.

\section{RESULTS AND DISCUSSION}

Cartilage is avascular tissue with a limited potential for repair in response to injury. Because chondrocytes are responsible for maintaining cartilage homeostasis, the use of substances that could damage the chondrocytes should be avoided. In our study, no differences $(\mathrm{P}<0.05)$ in the gene expression of MMPs, IL-6 and ACAN were observed between the TA and PRP-treated chondrocyte cell cultures when compared to and not compared to the control group (Figure $1 \mathrm{~A}-\mathrm{D}$ ). In relation to cell viability, there was no significant difference between the studied groups, being higher than $98 \%$.

Numerous biological and inflammatory changes are implicated in the etiopathogenesis of 
Table 1 - Real Time PCR primer sequences.

\begin{tabular}{lcc}
\hline Target & Accession & Primer sequence \\
\hline IL-6 $^{*}$ & NM_001082496.2 & F - TCCCTCTTCACAAGCACCGTC \\
& R - GTCTGCAGTGGTGAGTAGTGGT \\
ACAN $^{* *}$ & XM_014733894.1 & F - AGACAGCCGTCACAGACCAG \\
MMP13 $^{* * *}$ & NM_001081804.1 & ACGATGCTGCTCAGGTGTGA \\
MMP9 $^{* * * *}$ & NM_001111302.1 & R - ATGTTTAGGGTTCGGGTCTTC \\
\hline
\end{tabular}

Interlukin-6; ${ }^{* *}$ Aggrecan; ${ }^{* * *}$ Metalloproteinase-13; ${ }^{* * * *}$ Metalloproteinase-9.

osteoarthritis (OA). Once cartilage degradation has begun, pro-inflammatory cytokines are secreted and modulate the expression of MMP as well as they alter the cellular mechanisms of catabolic molecules, leading to an extended inflammation and destruction (ORTOLANO \& WENZ, 2014; ISHIGURO et al., 2002). Thus, it is important that drugs used in the treatment of OA do not induce major damage to the joints. These damages, induced by MMPs and IL, were not observed in vitro in our study.

Proteoglycans, mainly aggrecan, are major components of articular cartilage. Loss of aggrecan with proteolytic degradation mediated by activated MMPs and aggrecanase causes a significant loss of mechanical properties in cartilage (ISHIGURO et al., 2002). In this study, possibly because there was no change in the expression of MMPs and IL-6, no difference was observed in aggrecan concentration. No aggrecan increase was expected in healthy chondrocytes used in this study, since their quantity is regulated as required by ECM.

The main enzymes involved in ECM breakdown in OA are the MMPs. It has been shown that MMP-9 and MMP-13 play important roles in cartilage matrix destruction in arthritic joints, mainly causing type II collagen degradation, that will eventually lead to destabilization of the joint (ISHIGURO et al., 2002).

In our study, no change in MMP expression was observed, possibly because cells from healthy animals were used in a controlled environment that did not present challenging situations. Thus, it is possible to say that PRP and TA were not able to induce an increase of proteolytic enzymes by the cultured chondrocytes.
Inflammatory cytokines are responsible to the greatest extent for the loss of metabolic homeostasis of intra-articular tissues, by promoting catabolic processes (TORRERO \& MARTÍNEZ, 2015). The IL-6 strongly activates the immune system, usually as a response to IL- $1 \beta$ and TNF $\alpha$. Also, IL-6 causes a decrease in the production of type II collagen, and increases the production of MMP (GUERNE et al., 1990; PORÉE et al., 2008). Chondrocytes produce low levels of IL6 under normal conditions. However, a number of cytokines and growth factors are active in OA, such as IL1 $\beta$ stimulate IL6 production (KAPOOR et al., 2011). Furthermore, it is known that IL-6 acts synergistically with IL-1 and oncostatin $M$ to upregulate MMP-1 and MMP-13 in bovine and human cartilage explant cultures (PORÉE et al., 2008).

GUERNE et al. (1990) demonstrated that human chondrocytes isolated from normal and osteoarthritic joints released low levels of IL-6 when cultured in the presence of serum. Among the growth factors known to act on chondrocytes, only transforming growth factor-beta (TGF), but not epidermal growth factor (EGF), fibroblast growth factor (FGF), insulin growth factor-1 and 2 (IGF), platelet growth factor (PDGF) or insulin, was able to significantly increase IL-6 synthesis. Such findings may represent an advantage to the use of PRP, since this agent could be used without stimulation of this cytokine, avoiding a greater tissue inflammation in the absence of leukocytes in the PRP.

However, the role of IL- 6 on the depletion of the cartilage ECM remains controversial. Studies have demonstrated that injection of recombinant IL-6 in the joint cavity corrected the IL- 6 deficiency and significantly reduced cartilage destruction in the IL-6 gene knockout mouse model (van de LOO et al., 1997). 


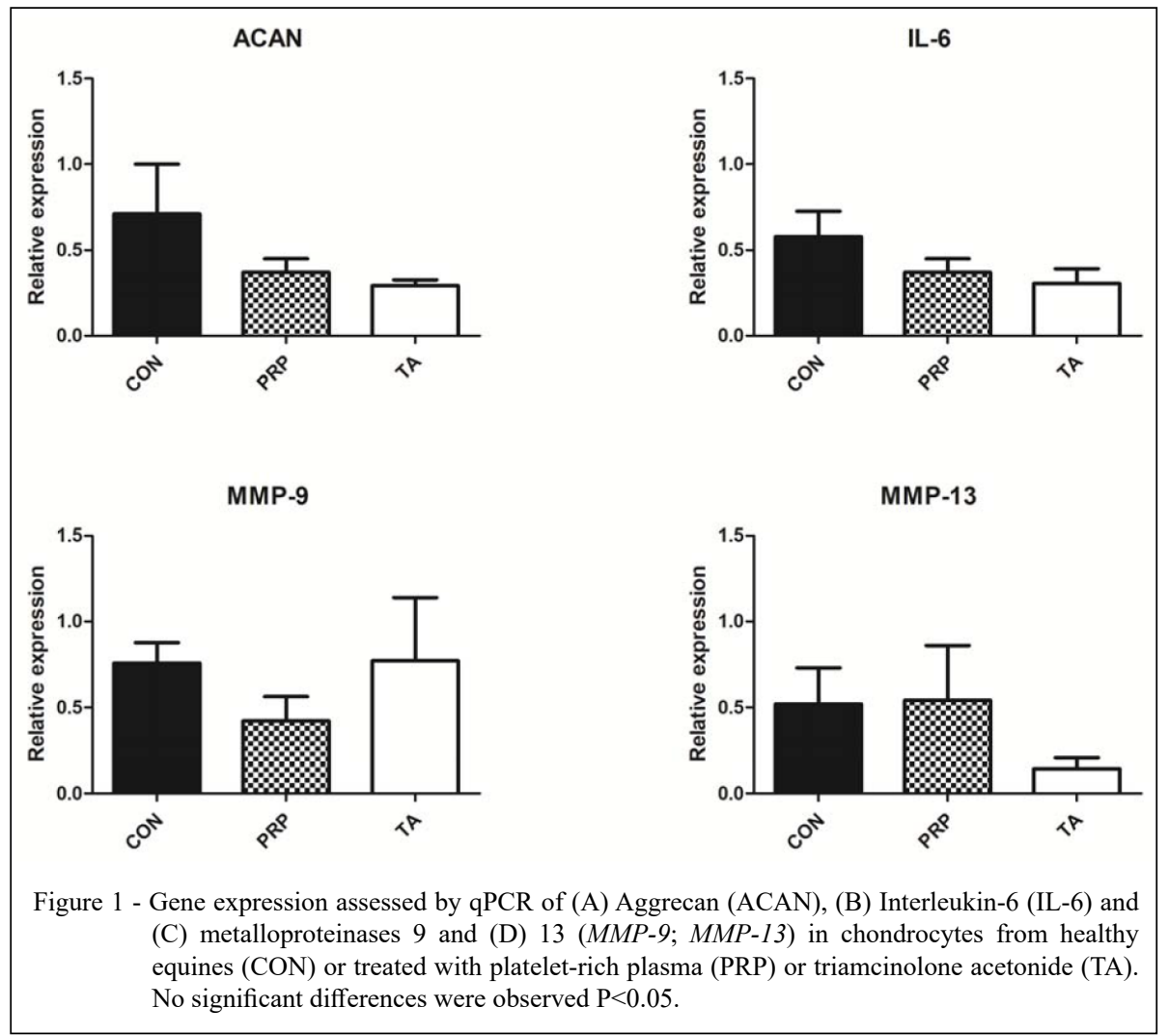

The possibility to perform intra-articular injections with corticosteroids or the treatment based on PRP has changed the management of OA disease. There are many scientific literature that describe the therapeutic potential of PRP. PRP exert positive effects on reestablishing homeostasis of joint tissues through a wide range of actions such as anti-inflammatory, immunomodulatory, and antioxidative effects, an analgesic effect, and finally chondroprotective and anabolic-trophic effects. The creation of chemotactic gradient would mediate cell recruitment and the onset of the healing process (TORRERO \& MARTÍNEZ, 2015; SANCHEZ et al., 2016). In our study, PRP exposure did not result in change in the gene expression of MMPs, IL-6 and ACAN. However, HUR et al. (2014) reported that PRP did not reduce expressions of MMPs, but reduced IL-6.

PORÉE et al. (2008) observed that when there is an increased leukocyte infiltration in synovial fluid there are also increased levels of IL- 6 . This is the reason why we decided to use the manually processed PRP in the cell culture in attempt to minimize the chances of contamination with inflammatory cells, avoiding an overexpression of pro-inflammatory cytokines that could stimulate IL-6 release.

Different from our study, some authors reported positive results with PRP in cartilage explants. RÍOS et al. (2015) and CARMONA et al. (2016) studied the in vitro effect of platelet-rich gel supernatant on culture media of normal equine synovial membrane and cartilage explants, and in both studies it was observed an increase in antiinflammatory and anabolic effects. GILBERTIE et al. (2018) used platelet lysate preparation instead of traditional PRP on equine synoviocytes and chondrocytes in vitro in a challenged articular environment, similar to OA. In this study, they observed interesting results regarding the effects of PRP lysate. There was an increase in collagen type II and aggrecan gene expression as well as decrease in MMP-13 expression. These results suggested that platelet-rich plasma can be a good therapeutic option for the treatment of osteoarthritis.

Since OA is caused by an imbalance between construction and destruction of cartilage ECM, understanding the effects of corticosteroids, which are most common therapeutic option used, on 
expressions of these proteinases and their inhibitors can be crucial to elaborate plans for OA patients (SUNTIPARPLUACHA et al., 2016). Intra-articular injections of corticosteroids rapidly resolve joint inflammation, synovitis, and signs of pain and are the gold standard of treatment for horses with osteoarthritis. Studies on TA reveal many beneficial effects on abnormal articular cartilage, including decreased IL-1-induced degradation, increased proteoglycan synthesis, and enhanced chondrocyte viability. SCHAEFER et al. (2009) observed that $0.6 \mathrm{mg} / \mathrm{mL}$ of TA had a protective effect against IL-1induced glycosaminoglycan degradation without any decrease in glycosaminoglycan synthesis.

SIEKER et al., in 2016, demonstrated that early intra-articular therapy with TA after joint injury entirely mitigates the injury-induced increase in synovial fluid collagen fragments in a preclinical model, resulting in values similar to those observed in healthy control animals.

On the other way, still regarding to TA, TEMPFER et al. (2009) observed that this drug reduced the expression and secretion of collagen I, and the expression of TIMP1 (a tissue inhibitor of MMPs) was upregulated, indicating a reduction in the cellular capacity for tissue repair. Expressions of these proteolytic enzymes are relatively low in normal condition, but they can be elevated by certain stimulations (SUNTIPARPLUACHA et al., 2016).

\section{CONCLUSION}

TA and PRP preparations have been shown to be safe to healthy chondrocytes in culture, they did not stimulate MMPs, and IL-6 synthesis or caused changes in ACAN gene expression. Nevertheless, more research is needed to understand the molecular mechanisms that drive the different biological effects and to explore new potential therapeutic alternatives for animals with osteoarthritis.

\section{ACKNOWLEDGEMENTS}

The authors thank Frigorífico Foresta, from São Gabriel, RS, Brazil and the pharmacist Zanoni Segala, for the financing of supplements to carry out the research. This study was funded by the Universidade Federal de Santa Maria- Fundação de Apoio à Tecnologia e Ciência (UFSM-FATEC) (5.03.0025 - grant), and was financed in part by the Coordenação de Aperfeiçoamento de Pessoal de Nível Superior (CAPES), Brazil - Finance code 001.

\section{DECLARATION OF CONFLICT OF INTERESTS}

The authors declare no conflict of interest. The founding sponsors had no role in the design of the study; in the collection, analyses, or interpretation of data; in the writing of the manuscript, and in the decision to publish the results.

\section{AUTHORS' CONTRIBUTIONS}

All authors contributed equally for the conception and writing of the manuscript. All authors critically revised the manuscript and approved of the final version.

\section{REFERENCES}

CARMONA, J.U. et al. In vitro effects of platelet-rich gel supernatants on histology and chondrocyte apoptosis scores, hyaluronan release and gene expression of equine cartilage explants challenged with lipopolysaccharide. BMC Vet Res., v.12, n.135, 2016. Available from: $<$ https://bit.ly/30ASz6Q $>$. Accessed: May, 15, 2019. doi: 10.1186/s12917-016-0759-8.

CRUZ, T.F. et al. Inverse correlation between tyrosine phosphorylation and collagenase production in chondrocytes. Biochem. J., v.269, p.717-721, 1990. Available from: < https://bit. ly/2WU4Sc9>. Accessed: May, 15, 2019. doi: 10.1042/bj2690717.

GOLDRING, S.R.; GOLDRING, M.B. The role of cytokines in cartilage matrix degeneration in osteoarthritis. Clin Orthop Relat Res., v.427, p. 27-36, 2004. Available from: <https:// bit.ly/2EjUB1K>. Accessed: May, 15, 2019. doi: 10.1097/01. blo.0000144854.66565.8f

GUERNE, P.A. et al. IL-6 production by human articular chondrocytes. Modulation of its synthesis by cytokines, growth factors, and hormones in vitro. J Immunol, v.144, n.2, 1990. Available from: $<$ https://bit.ly/2HFOYf5>. Accessed: May, 15, 2019.

DECHANT, J.E. et al. Effects of dosage titration of methylprednisolone acetate and triamcinolone acetonide on interleukin-1-conditioned equine articular cartilage explants in vitro. Equine vet. J., v.35, n.5, p.444-450, 2003. Available from: <https://bit.ly/2VBrLzP >. Accessed: May, 15, 2019. doi: $10.2746 / 042516403775600479$.

GILBERTIE, J.M. et al. Pool platelet-rich plasma lysate therapy increases synoviocyte proliferation and hyaluronic acid production while protecting chondrocytes from synoviocytederived inflammatory mediators. Front Vet Sci., v.5, n. 150, 2018. Available from: <https://bit.ly/30BUZlC $>$. Accessed: May, 15, 2019. doi: $10.3389 /$ fvets. 2018.00150 .

HUR, C.I. et al. Effect of Autologous Platelet-Rich Plasma on IL-6, MMP-3 and MCP-1 Expression in Synoviocytes from Osteoarthritic Patients Knees. Open Journal of Regenerative Medicine, v.3, p.64-72, 2014. Available from: <https://bit.ly/2Hw12Rv>. Accessed: May, 15, 2019. doi: 10.4236/ojrm.2014.33008.

ISHIGURO, N. et al. Mechanism of cartilage destruction in osteoarthritis. Nagoya J. Med. Sci., v.65, p.73-84, 2002. Available from: <https://bit.ly/2QbNU6L>. Accessed: May, 15, 2019.

KAPOOR, M. et al. Role of proinflammatory cytokines in the pathophysiology of osteoarthritis. Nat. Rev. Rheumatol., v.7, p.33-42, 2011. Available from: <https://bit.ly/2VHbHwm>. Accessed: May, 15, 2019. doi: 10.1038/nrrheum.2010.196.

ORTOLANO, G.A.; WENZ, B. A Review of the Pathogenesis of Osteoarthritis and the Use of Intra-articular Platelet Therapy 
for Joint Disease in Animals and Humans. Bone and Tissue Regeneration Insights, v.5, 2014. Available from: <https://bit. ly/2VSVOaZ>. Accessed: May, 15, 2019. doi: 10.4137/BTRI. S14578.

PEREIRA, R.C.F. et al. Evaluation of seven platelet-rich plasma processing protocols in the equine species. Ciência Rural, v.43, n.6, p.1122-1127, 2013. Available from: <https://bit. ly/2JuBZAs>. Accessed: May, 15, 2019. doi: 10.1590/S010384782013005000052 .

PFAFFL, M.W. A new mathematical model for relative quantification in real-time RT-PCR. Nucleic Acids Res, v.29, n.45, 2001. Available from: $<$ https://bit.ly/2QhBJVV $>$. Accessed: May, 15, 2019. doi: 10.1093/nar/29.9.e45.

PORÉE, B. et al. Interleukin-6 (IL-6) and/or soluble IL-6 receptor down-regulation of human type II collagen gene expression in articular chondrocytes requires a decrease of Sp1Sp3 ratio and of the binding activity of both factors to the COL2A1 promoter. The Journal of Biological Chemistry, v.283, n.8, p.4850-4865, 2008. Available from: $<$ https://bit.ly/2M9MRpg>. Accessed: May, 15, 2019. doi: $10.1074 /$ jbc.M706387200

RÍOS, D.L. et al. Evaluation of the anti-inflammatory effects of two platelet-rich gel supernatants in an in vitro system of cartilage inflammation. Cytokine, v.76, n.2, p.505-513, 2015. Available from: <https://bit.ly/30yBudT>. Accessed: May, 15, 2019. doi 10.1016/j.cyto.2015.07.008.

SANCHEZ, M. et al. A new strategy to tackle severe knee osteoarthritis: Combination of intra-articular and intraosseous injections of Platelet Rich Plasma. Expert Opin Biol Ther., v.16, p.627-643, 2016. Available from: <https://bit.ly/2YEGwUf $>$. Accessed: May, 15, 2019. doi: 10.1517/14712598.2016.1157162.

SANDLER, E.A. et al. A dose titration of triamcinolone acetonide on insulin-like growth factor-1 and interleukin-1 conditioned equine cartilage explants. Equine vet. J., v.36, n.1, p.58-63, 2004. Available from: <https://bit.ly/2HweSDr>. Accessed: May, 15, 2019. doi: $10.2746 / 0425164044864615$.
SCHAEFER, E.C. et al. Effects of sodium hyaluronate and triamcinolone acetonide on glucosaminoglycan metabolism in equine articular chondrocytes treated with interleukin-1. Am J Vet Res, v.70, n.1494-1501, 2009. Available from: <https:// bit.ly/2WVL2NZ>. Accessed: May, 15, 2019. doi: 10.2460/ ajvr.70.12.1494

SIEKER, J.T. et al. Immediate Administration of Intraarticular Triamcinolone Acetonide After Joint Injury Modulates Molecular Outcomes Associated With Early Synovitis. Arthritis \& Rheumatology, v.68, n.7, p.1637-1647, 2016. Available from: $<$ https:// bit.ly/2WjdzzU>. Accessed: May, 15, 2019. doi: 10.1002/art.39631.

SUNTIPARPLUACHA, M. et al. Triamcinolone acetonide alters expressions of matrix metalloproteinase- 3 gene in primary human chondrocytes. Genomics and Genetics, v.9, n.2, p.1-6, 2016. Available from: <https://bit.ly/2JuJWpb>. Accessed: May, 15, 2019. doi: 10.14456/gag.2016.9.

TEMPFER, H. et al. Effects of crystalline glucocorticoid triamcinolone acetonide on cultured human supraspinatus tendon cells, Acta Orthopaedica, v.80, n.3, p.357-362, 2009. Available from: <https://bit.ly/2EilVen>. Accessed: May, 15, 2019. doi: $10.3109 / 17453670902988360$.

TEXTOR, J.A.; TABLIN, F. Intra-articular use of plateletrich product in normal horses: clinical signs and cytologic responses. Veterinary Surgery, v.42, p.499-510, 2013. Available from: <https://bit.ly/2Qdce8c $>$. Accessed: May, 15, 2019. doi: 10.1111/j.1532-950X.2013.12015.X.

TORRERO, J.I.; MARTÍNEZ, C. New developments in the treatment of osteoarthritis - focus on biologic agents. Open Access Rheumatology: Research and Reviews, v.7, 2015. Available from: <https://bit.ly/2JUKqEv>. Accessed: May, 15, 2019. doi: 10.2147/OARRR.S50058.

Van de LOO, F.A. et al. Interleukin-6 reduces cartilage destruction during experimental arthritis. A study in interleukin-6-deficient mice. Am J Pathol., v.151, n.1, p.177-191, 1997. Available from: $<$ https://bit.ly/2M011YM>. Accessed: May, 15, 2019 